\title{
O MUNDO NOS TEXTOS LITERÁRIOS: RELEITURAS DA INTERPRETAÇÃO E POSSIBILIDADES EM SALA DE AULA
}

http://dx.doi.org/10.11606/issn.2237-1184.v0i23p139-162

\section{RESUMO}

O artigo traça uma ponte entre os pensamentos de três autores contemporâneos, Luiz Costa Lima, Hans Ulrich Gumbrecht e Paul Ricoeur, para repensar a imposição de interpretações - ou da necessidade de interpretação, no caso de Gumbrecht - na abordagem da leitura literária na escola, em especial no ensino médio, onde essas imposições se fazem mais presentes. Para tanto, parte-se de suas obras para estabelecer o caminho histórico da relação entre obra literária e atribuição de sentido, assim como do conceito da mimesis artistótelica e de sua leitura renascentista, sempre com foco nas novas possibilidades no que diz respeito à busca de uma experiência literária mais completa para a formação de novos leitores.

\section{ABSTRACT}

This articles aims at connecting the thoughts of three contemporary authors Luiz Costa Lima, Hans Ulrich Gumbrecht and Paul Ricoeur - on the subjects of representation, interpretation and aesthetic experience, linking those reflections to the way literary works are approached in school, particularly in Secondary Education, when trying to find the "correct" meaning of texts is a central activity. We read Costa Lima, Gumbrecht and Ricouer's thoughts on the historical place of meaning and interpretation and on the concept of mimesis in order to find new possibilities for a more generous approach on literary experiences in class.
Ligia Gonçalves Diniz

Universidade de Brasília
PALAVRAS-CHAVE:

representação.

experiência estética. interpretação. ensino de literatura. leitura.

\section{KEYWORDS:}

representation. a esthetic experience. interpretation. literature classes. reading. 


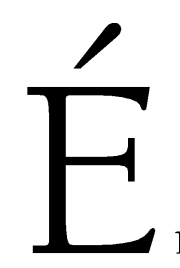

muito complicado, se não impossível, conseguirmos pôr em palavras o que nos acontece - a experiência por que passamos - quando lemos um livro incrível. "Incrível", é claro, é uma definição a posteriori: dizemos que um livro é incrível justamente porque ele nos oferece algo que dificilmente poderemos esclarecer, de forma mais explícita, para outra pessoa, a não ser que tenha passado por exatamente a mesma experiência, o que, concretamente, jamais acontece. Sabemos, às vezes intuitivamente, que uma experiência estética é única, e tanto mais única quanto é intensa. Ainda assim, insistimos, quando pensamos no ensino de literatura, sobretudo no ensino médio - quando já deixamos a leitura lúdica de lado, mas ainda não entramos no campo da reflexão que deve ser o domínio universitário -, na concepção de que a formação de leitores se dá tão somente por uma relação explicável e, geralmente, centrada em experiências plenamente compartilháveis, pois fundamentadas no que "o texto quer dizer", como se um texto sempre quisesse dizer - e dissesse - uma coisa somente.

Este artigo pretende repensar as potencialidades de abordagem da literatura em sala de aula a partir de uma perspectiva que busque enxergar a leitura literária como duas espécies possíveis de experiência - essa acima definida como única, inexplicável e intensa, e aquela esboçada como explicável, centrada em uma interpretação e em um sentido. Nesse contexto, este texto propõe uma discussão teórica, não centrada em um estudo de caso ou trabalho de campo. É antes uma reflexão que possibilitará um olhar diferente sobre esse tipo de observação, tendo como centro de irradiação a ideia de representação - uma representação sem complemento nominal específico, como um conceito que define, aqui, a relação entre a obra/autor e o leitor, e que só pode ter como horizonte comum o mundo. É justamente a apreensão desse mundo via leitura literária que está em jogo nesta discussão: entendemos, assim, a representação como qualquer manifestação do mundo em uma obra, por meio do qual o leitor possa interagir com ela, o que pressupõe, é claro, tanto uma ideia de referencial passível de reconhecimento e comunicação quanto uma relação entre texto e realidade.

Essa relação está no cerne das propostas reflexivas que se iniciam na próxima seção e que têm como ponto de partida as ideias de Luiz Costa Lima 
e Paul Ricoeur, que realizam releituras da mimesis aristotélica, para então encontrar uma forma mais radical em Hans Ulrich Gumbrecht, que propõe uma alternativa ao próprio paradigma da representação, entendido por ele como apreensão do mundo exclusivamente centrada na interpretação e na busca de sentido. Com base na retomada de caminhos históricos realizada sobretudo pelo dois primeiros, e a partir do universo de possibilidades desvelado por uma leitura não mais calcada na necessidade única de desvendar sentidos, este artigo pretende contribuir para novos modos de enxergar a relação entre livros e leitores.

\section{Costa Lima e a representação-efeito}

Luiz Costa Lima recupera momentos chave do pensamento moderno para repensar a mimesis não mais como a subordinação da arte à natureza, mas pelo viés do que vai chamar de representação-efeito. Confrontando toda uma concepção de um sujeito uno, cartesiano, a só se ocupar do que poderia se propor como objeto de investigação científica, surge um sujeito fraturado que observa e que se observa, "apresenta e recebe, produz e suplementa" ${ }^{\text {. }}$ O que o autor busca empreender é uma argumentação rumo à ideia de que o sujeito segue em posição inapagável na teoria literária (como também na história), mas não mais como um sujeito cuja totalidade é visível para o outro e para si próprio. Da mesma forma, a representação não é mais fruto da intenção desse sujeito, já que a representação que ele recebe do mundo, assim como a que produz sobre ele, também está cindida. O movimento que se dá antes dessa reabilitação do sujeito tem a ver com o deslocamento da natureza enquanto objeto de contemplação para objeto de experimentação/transformação. Também o próprio sujeito passa a ser objeto de investigação racional: não é mais entendido nem intuído, mas pensado. Esse pensamento produz então outro tipo de representação - sendo produção, passa a ser uma apresentação, e uma apresentação duplamente distante de uma possibilidade de unicidade, já que produzida por um sujeito fraturado que lê e produz representações necessariamente fraturadas. Há um momento, portanto, e ainda estamos em Kant, em que "a imaginação ultrapassa a função de subordinada ao entendimento", e a matéria ultrapassa o conceito - a mimesis passa a funcionar como produção².

\footnotetext{
${ }^{1}$ LIMA, Luiz Costa. Mímesis: desafio ao pensamento. Rio de Janeiro: Civilização Brasileira, 2001. p. 284.

2 Ibidem, p. 122-113. 
É nesse viés que Costa Lima entende a possibilidade de um segundo sentido de representação, que não a de uma construção humana de algo prévio a ela ${ }^{3}$, mas sim daquilo que denomina "representação-efeito", esta relacionada não a uma cena anterior, ou objeto pré-existente, mas à expressão desses referenciais em um receptor, excluindo a sinonímia vastamente estabelecida pelo Renascimento entre mimesis e imitação. Com isso, os limites da representação saem da natureza dada rumo a um "horizonte cultural de expectativas": não se trata mais de estabelecer uma figuratividade que funciona como parâmetro de reconhecimento, mas da construção de um sentido a partir do confronto do objeto com um horizonte mais amplo, e mais subjetivo. A partir daí, "o sentido que [...] se configura se comprova pelo efeito que provoca. Sentido - efetivação de uma expectativa cultural - e efeito (do sentido) formam pois o arco e a correspondência indispensáveis para a atualização da mímesis" ${ }^{4}$.

Não cabe aqui retomar todo o caminho traçado por Costa Lima, mas vale lembrar que, a partir do Renascimento, com o desenvolvimento de uma forma de apropriação da realidade calcada na razão e no entendimento - isto é, em operações que dependem de uma subjetividade racional - em oposição ao conhecimento "dado" por Deus e apenas "recebido" pelo homem, deslocaram-se tanto os lugares ocupados pela ficção quanto as possibilidades de interação com os produtos da ficção (e do imaginário), dentro dos limites operados pela relação com a "verdade". Em posição central está, vê-se bem, a questão da interpretação: caminhamos desde o estabelecimento de um único sentido possível para cada experiência ou objeto (o que implicava ser desnecessária a própria referência a "um sentido"), calcado na cosmologia cristã medieval, a priori atemporal, em direção à busca de um sentido obtido pelas operações racionais - nasce a subjetividade, mas ainda se busca uma pedra de toque, instaurada então no entendimento racional. De qualquer modo, sendo ainda o objetivo chegar a uma "verdade", não se trata de qualquer entendimento racional, mas de uma hierarquia de entendimentos possíveis: as subjetividades não estavam (e ainda não estão) em um plano de igualdade ${ }^{5}$.

Focando especificamente a literatura, pensada a partir do século XVII, Costa Lima recorda o descaso pela ideia de ficção e a reverência aos modelos clássicos e seus parâmetros objetivos, mediados pela valorização da

\footnotetext{
${ }^{3}$ Ibidem, p. 230

${ }^{4}$ Ibidem, p. 233

${ }^{5}$ Ver: LIMA, Luiz Costa. O controle do imaginário: razão e imaginação nos tempos modernos. 2. ed. Rio de Janeiro: Forense Universitaria, 1989 , p. 20 e seguintes. 
linguagem, entendida como forma nobre e elegante - uma forma de garantir algum espaço entre os discursos legitimados. É nesse contexto que há uma reapropriação da mimesis aristotélica como imitação (imitatio): a subjetividade se exprime na escolha da forma mais elegante para reconfigurar os modelos clássicos. Esse processo não é, claramente, exaustivo, mas expõe em linhas gerais como se enxergavam as possibilidades e limites da produção artística, notadamente da literatura.

Como veremos também em Ricoeur, Costa Lima procura entender como, para seus próprios fins, o Renascimento lê Aristóteles: o autor afirma, em obra da década de 1980, que a mimesis aristotélica se ocupava do possível, enquanto a imitatio renascentista vai se preocupar com o verossímil, que "depende do que já é, do atual, então confundido com o verdadeiro" ${ }^{6}$. A imitatio se daria, portanto, sob "parâmetros de uma razão pragmática, voltada para o mais rotineiro dos cotidianos", que protegia a "verdade" do fingimento, da mentira propostos pela ficção. Mais recentemente, contudo, Costa Lima reabilita o uso de "verossímil" como algo que "aponta para a importância do receptor, enquanto este reconhece a dinâmica do efeito, e, ao mesmo tempo, aponta para o caráter antes tortuoso do que reto do acesso à ousía", isto é, à essência. Nessa leitura, a mimesis aristotélica não é prescritiva, pois exige, implicitamente, uma atitude criativa tanto do artista quanto do receptor, descartando a eficiência absoluta de fórmulas. Diferentemente, diz Costa Lima, a leitura renascentista da mímesis, ao revesti-la da forma de imitatio, torna-a normativa: o que o autor chama de "veto à ficção" nada mais é do que a reafirmação de um sentido único, verdadeiro, que - para ser único, verdadeiro - requeria a qualidade da universalidade e da atemporalidade de leis e valores, fundamento do culto à univocidade da razão, em oposição à pluralidade da imaginação ${ }^{7}$.

Se essa reflexão, emprestada de Costa Lima, é proposta aqui é porque, mesmo muita água tendo corrido desde então, muitos desses procedimentos e princípios se mantêm presentes, menos ou mais explícitos, na abordagem da literatura que ainda se faz em contextos como o escolar, calcado justamente no estabelecimento hierarquizado de subjetividades possíveis traduzido na estreiteza e arbitrariedade de interpretações e julgamentos, que giram em torno de alguma noção de verdade ${ }^{8}$. "A prática ocidental da

\footnotetext{
${ }^{6}$ Ibidem, p. 32

${ }^{7}$ Ibidem, p. 44-45

${ }^{8}$ Em alguns casos, chega-se ao ridículo. Em um livro didático para ensino médio, após a leitura do "Poema de sete faces" (Carlos Drummond de Andrade), pergunta-se: "De acordo com essa estrofe [a última], o conhaque e a atmosfera noturna deixaram o eu lírico comovido. É como se todo o poema fosse fruto da bebedeira, não fosse coisa séria. Na sua opinião, o eu lírico estaria falando sério ou estaria blefando? Por quê?". Segue a resposta sugerida: "Blefando, pois os assuntos de que trata são profundos, 143 | E N S A I O S
} 
verdade só tem sido capaz de tolerar o ficcional enquanto o dobra e domestica, i. e., enquanto pode nele reconhecer a encenação alegórica de uma parcela sua", escreve Costa Lima9.

O que parece variar, se seguirmos o pensamento de Costa Lima, são os modos de domesticação da ficção. Quando nos detemos no século XVIII, observamos, por exemplo, duas novas formas de moldar a ficção para legitimá-la, reafirmando sua dependência da realidade, ou recusando-a totalmente, isto é, desprendendo a ficcionalidade do mundo. É a partir da noção de gênio, tão cara ao Romantismo, e da elevação da história como área de conhecimento, que Costa Lima propõe o início de uma cisão que irá se concretizar plenamente entre o final do século XIX e o começo do XX: aquela entre a mimesis e a poiesis, ou, contextualizando-se, entre a "arte pela arte" e o realismo, ambos originados na necessidade de oferecer uma nova legitimação à arte. Mantém-se o veto à ficção, no primeiro caso, pela autossuficiência da arte em relação ao "mundo", seu alheamento à questão da verdade (e, assim, sua não ameaça); no segundo, a ideia da obra de arte como reflexo da realidade dá fôlego ao atrelamento entre literatura e história. Já no século $\mathrm{XX}$, os new critics representam com exemplaridade um novo viés da relação ficção/realidade: a defesa de um novo tipo de verdade, a do texto literário. A ideia é: se o controle do imaginário estabelece sempre uma proteção da verdade contra a ficção, crie-se uma nova verdade, propondo-se uma espécie de antirreferencialidade: considerando-se que os românticos haviam trocado uma referência por outra - a imitatio vs. o eu do poeta -, o que se defende agora é que a verdade só pode estar dentro do poema, na própria linguagem, e aos críticos cabe comentar ou, no máximo, traduzir a verdade poética ${ }^{10}$.

Nesse contexto, o mérito da reabilitação da mimesis proposta por Costa Lima é o de, a partir da crítica de uma visão do fenômeno literário imbricado à subordinação da ficção à realidade, propor uma concepção da mimesis como uma experiência histórica e culturalmente variável e, sobretudo, calcada nas experiências subjetivas do leitor, na medida em que provoca, de início, uma sensação de semelhança derivada da "correspondência com os quadros de referência e as expectativas daí resultantes". Essas referências e expectativas têm a ver com as experiências e

\footnotetext{
existenciais, universais". CEREJA, William R.; MAGALHÃES, Tereza C. Português: linguagens, ensino médio. V. 2. 5. ed. São Paulo: Saraiva, 2008, p. 216-217.

${ }^{9}$ LIMA, Luiz Costa. O fingidor e o censor: no ancien régime, no iluminismo e hoje. Rio de Janeiro: Forense Universitária, 1988, p. 308.

${ }^{10}$ Ibidem, p. 328-330.
} 
valores do autor - já que há entre este e a obra uma relação de continuidade - mas também do leitor, cuja intervenção "não se limita a explicitar o que o texto já traria de forma implícita, pois quem assim afirme postula a existência, pelo menos ideal, de uma única interpretação correta". Para Costa Lima, a intervenção do leitor é "pluralizadora, pois que dependente da atividade do imaginário do receptor" ". Definindo assim a mimesis, o autor já anunciava o que viria a chamar mais tarde de "representação-efeito". Nesse sentido, Costa Lima recupera algo da mimesis aristotélica, que, diz ele, ensina, diferentemente da elaboração renascentista, "que é preciso aprender a viver sobre dupla via e não sobre a via única da verdade alcançada pelo pensamento" - via dupla que significa que a mimesis "não só recebe o que vem da realidade mas é passível de modificar nossa própria visão da realidade" $" 12$.

\section{Ricoeur e o tempo humano}

Paul Ricoeur também volta a Aristóteles para se reapropriar de sua proposta de mimesis. Pensando as proposições do grego, ele lembra a definição da tragédia como a representação de uma ação completa formando um todo, sendo este o que possui princípio, meio e fim ${ }^{13}$. Ricoeur argumenta, entretanto, que a noção de "todo" tem um caráter menos temporal do que lógico, na medida em que, na Poética aristotélica, "o princípio não vem depois de coisa alguma necessariamente; é aquilo após o qual é natural haver ou produzir-se outra coisa; o fim é o contrário: produz-se depois de outra coisa, quer necessariamente, quer segundo o curso ordinário, mas depois dele nada mais ocorre" ${ }^{14}$. Ricoeur, nesse contexto, afirma que a lógica aristotélica do todo não é de viés teórico, mas prático e poético, e propõe a entrada em cena de um receptor a quem se reserva uma fruição: "Aprender, concluir, reconhecer a forma: eis o esqueleto inteligível do prazer da imitação (ou da representação)"15.

Ricoeur recupera na Ética a Nicômaco uma noção que Aristóteles oferece sobre o prazer, para confrontar essa ideia com sua poética da tragédia, tentando desvelar o papel do espectador na experiência da mimesis e voltar a falar no prazer de entender, que ele faz coincidir com o de reconhecer e que é

\footnotetext{
${ }_{12}^{1}$ LIMA, Luiz Costa. O controle do imaginário. Op. cit., p. 68-69.

${ }^{12}$ LIMA, Luiz Costa. Mímesis: desafio ao pensamento. Op. cit., p. 32.

${ }^{13}$ ARISTÓTELES. Poética, VII, 3. Disponível em: http://www.psb40.org.br/bib/b2.pdf. Acesso em: 10 mar. 2014.

${ }^{14}$ Ibidem, VII, 4-5.

${ }^{15}$ RICOEUR, Paul. Tempo e narrativa. v. 1. São Paulo: Papirus, 1994, p. 68 
"o fruto do prazer que o espectador tira de uma composição que respeita o necessário e o verossímil. Ora, esses critérios 'lógicos' são, eles próprios, ao mesmo tempo, construídos na peça e exercidos pelo espectador"

Interessa menos fazer uma retomada detalhada da leitura de Ricoeur do que colocá-la entre outras leituras contemporâneas que visam reabilitar a mimesis, abordando-a pelo viés da recepção. Nesse sentido, ele está em consonância com Costa Lima, ainda que observe a questão por outro viés - a concepção do tempo humano como tempo narrado - ao dizer que a representação de uma ação é a pré-compreensão do agir humano, tanto no que toca o entendimento/sentido quanto a temporalidade. É sobre essa précompreensão, diz Ricoeur, "comum ao poeta e a seu leitor, que se ergue a tessitura da intriga e, com ela, a mimética textual e literária" ${ }^{17}$. Dessa forma, assim como Costa Lima, o francês entende a mimesis como uma experiência que se estende, ou se estabelece, entre autor, obra e receptor. A ideia de temporalidade não aparece de forma fortuita: o ponto de partida de Ricoeur é entender a narrativa (aqui, a tragédia) como uma forma de solução - poética - para o paradoxo do tempo. A relação leitor-obra via temporalidade é uma das principais diferenças em relação à proposta que Gumbrecht vai fazer e que encerra a leitura teórica deste artigo.

A mimesis como recepção recebe de Ricoeur o nome de "mimese III", seguindo-se a dois momentos anteriores. A "mimese I" seria, para ele, a préconfiguração de um referente, ou de um mundo, e de uma noção de temporalidade, e a mediatização simbólica que a permite, e que é compartilhada pelo autor e pelo leitor, para que os estágios seguintes da mimese sejam possibilitados ${ }^{8}$. A partir da mimese I, a "mimese II" - a própria "tessitura da intriga" aristotélica - medeia o mundo-referente: de uma diversidade de eventos, essa operação extrai a unidade de uma totalidade temporal, ou seja, "uma configuração de uma sucessão". Como se viu, Ricoeur vai considerar essa atividade uma solução poética para o paradoxo que Agostinho apontou para a relação distenção-intenção suscitada pela questão do tempo ${ }^{19}$ : conjugando dinamicamente expectativa, atenção e memória (futuro no presente, presente e passado no presente), "que a história se deixe seguir converte o paradoxo em dialética viva" ${ }^{20}$. Como mediação, a mimese II será a via entre a mimese I e a "mimese III", ou seja,

\footnotetext{
${ }^{6}$ Ibidem, p. 81.

${ }^{7}$ Ibidem, p. 101

${ }^{18}$ Ibidem, p. 88.

${ }^{19}$ AGOSTINHO. Confissões. 24. ed. Rio de Janeiro: Vozes, 1987.

${ }^{20}$ Ibidem, p. 104-105.

146| E N S A I O S
} 
entre a pré-configuração paradigmática do mundo e a experiência concreta de fusão entre mundo do autor e mundo de leitor, isto é, a leitura. Aqui Ricoeur retoma a questão da narrativa como intrínseca à experiência humana ("transcultural", em seus termos): "Se não existe experiência humana que não seja já mediatizada por sistemas simbólicos e, dentre eles, pelas narrativas, parece (...) que a ação está em busca de narrativa" ${ }^{21}$.

A partir daí Ricoeur estabelece uma relação entre sentido e experiência que, de alguma forma, se comunica com Costa Lima ao mesmo tempo que serve como introdução para o próximo, e mais radical, parti pris teórico a ser abordado neste artigo. Enquanto Costa Lima entende que do sentido obtido a partir do horizonte histórico-cultural se produzirá o efeito da mimesis na recepção, Ricoeur afirma que aquilo que um leitor recebe não é apenas o sentido da obra mas, "por meio de seu sentido, sua referência, ou seja, a experiência que ela faz chegar à linguagem e, em última análise, o mundo e sua temporalidade, que ela exibe diante de si" ${ }^{\prime 2}$. A leitura coloca, assim, o problema da intersecção do mundo do texto com o mundo do leitor. O sentido ainda ocupa posição central, na medida em que Ricoeur entende a relação das obras com o mundo como uma relação de referência metafórica em que o desaparecer da referência descritiva "revela-se ser, numa segunda aproximação, a condição negativa para que seja liberado um poder mais radical de referência a aspectos de nosso ser-no-mundo que não podem ser ditos de maneira direta" ${ }^{23}$. A ideia de interpretação e de significado aparece com força: interpreta-se em um texto a proposta de um mundo possível, ao mesmo tempo que o fazer narrativo "re-significa o mundo na sua dimensão temporal".

Tanto Costa Lima quanto Ricoeur apontam para o fato de que há uma tendência histórica de se observar a experiência literária sob a luz de uma leitura enviesada da poética aristotélica que remete à ideia de representação como produção de uma forma de referencialidade unívoca; e, cada um a seu modo, ambos indicam a relevância de se observar a noção de representação em sua carga de interação e de lastro entre produção e recepção, autor e leitor - o quer dizer uma relação mais generosa e produtiva entre ficção e realidade. É esse último ponto que nos parece fundamental não apenas para pensar a literatura em contexto de formação de leitores, mas também para

${ }^{21}$ Ibidem, p. 114.
22 Ibidem, p. 120.
23 Ibidem, p. 122.

$147 \mid$ E N S A I O S 
reivindicar maior espaço para esse debate entre os pesquisadores e teóricos de literatura.

$O$ argumento de que a fixação escolar em retirar interpretações verdadeiras de textos literários tem mais a ver com uma especificidade da escola enquanto instituição - com seu papel de transmitir e/ou impor um arbitrário cultural $^{24}$, e a correlacionada necessidade de determinar a diferença entre certo e errado, condição para que se estabeleçam critérios aplicáveis de avaliação - não exclui a responsabilidade de teóricos e estudiosos da literatura buscarem, dentro do arcabouço mais próprio à área, uma explicação, trajetória ou escape a uma abordagem da literatura tão avessa à participação de uma subjetividade menos circunscrita e limitada; especialmente se o objetivo propalado é o de "formar leitores"25. Isso porque, entre aprender o funcionamento formal, ou o contexto sócio-histórico das obras, e a leitura de fruição - a experiência de leitura literária propriamente dita -, não há uma separação estanque, antes uma relação dialética, em movimento, em que uma deve contribuir à outra, de forma fluida.

No Brasil, como se sabe, vingou no século XIX a valorização da literatura como capítulo da história nacional. Da mesma forma, no ensino de literatura no Brasil, passamos de uma tradição retórico-poética, baseada nos valores "universais" e na formação integral do indivíduo, herança dos colégios jesuítas, a, no final do século XIX, uma priorização da literatura nacional, com foco duplo entre a literatura portuguesa e a incipiente literatura brasileira, sob um viés positivista-cientificista, o que desembocou na vitória, ainda hoje reiterada, da historiografia literária ${ }^{26}$. Dos movimentos de vanguarda artística e literária que marcaram a Europa entre os séculos XIX e XX, e da autonomia da arte proposta pelo new criticism, a herança mais evidente é, do ponto de vista da leitura e, mais especificamente, da relação entre literatura e não leitores ou leitores em formação, no Brasil, além de uma imobilização da própria definição de literatura (uma proteção à poesia e à narrativa de ficção como formas literárias verdadeiras), a acentuada elitização do acesso à "alta cultura”, como domínio sob uma aura sagrada, em descompasso com as demais conquistas sociais.

Esse descompasso, no que diz respeito à abordagem da literatura no ambiente escolar, se nutre justamente de uma ainda forte imposição de

\footnotetext{
${ }^{24}$ Ver, sobre isso: BOURDIEU, Pierre. A economia das trocas simbólicas. São Paulo: Perspectiva, 2004.

${ }^{25}$ BRASIL. Orientações curriculares para o ensino médio. V. 1 - Linguagens, códigos e suas tecnologias. Brasília: Ministério da Educac, ão Secretaria de Educac, ão Básica, 2006, p. 71.

${ }^{26}$ Ver, sobre isso: CEREJA, William R. Ensino de literatura: uma proposta dialógica para o trabalho com literatura. São Paulo: Atual, 2005, p. 89-126.

$148 \mid$ E N S A I O S
} 
interpretações e, particularmente, julgamentos únicos, assim como da velha noção de literatura como fonte de valores e princípios universais, justapostos às noções de gênio do autor e de gosto, impositoras de juízos. É como se o ensino escolar de literatura houvesse escolhido a dedo o que de menos generoso pudesse herdar de cada uma das concepções históricas de ficção e literatura para determinar um modelo quase cristalizado de abordagem desde o final do século XIX e início do XX, com toques aqui e acolá de uma crítica marxista que cobra o engajamento da literatura nas questões sociopolíticas. É claro que as décadas de ouro da teoria da literatura, em meados do século XX, deixaram outras marcas no ensino de literatura, algumas com maior alcance que outras, ou mais explicitamente que outras. $\mathrm{O}$ dialogismo bakhtiniano, e sua apropriação francesa como intertextualidade, aparece em propostas de leituras sincrônicas em alguns livros didáticos de língua portuguesa para ensino médio, por exemplo; no entanto, ainda não parece que todos os autores tenham feito pesquisas de "repertório" que permitam ir muito além das diferentes "canções do exílio", de Gonçalves Dias a José Paulo Paes ${ }^{27}$. Da mesma forma, a volta da historicidade proposta pela Estética da Recepção também gerou frutos mais em uma perspectiva teórica do que na prática da abordagem da literatura na escola: se se reconhece que a leitura de uma obra ganha complexidade ao se a inserir em um contexto histórico de produção e recepção, esse contexto ainda é proposto no ensino médio, essencialmente, a partir da organização em escolas, estilos e períodos literários, de forma geral homogeneizadores.

As teorias do século XX aparecem especialmente no que diz respeito à atualização dos estudos dos gêneros literários, tarefa incontornável. Ainda assim, de forma geral, a empreitada segue os procedimentos gerais quando o foco são as categorias conceituais de literatura, começando pela própria noção do que é um texto literário: descrevem-se o que soam como categorias estáveis. Assim, ainda que não se retome o caráter prescritivo das teorias clássicas - o que implicaria ignorar as especificidades de textos relevantes do século XX, por exemplo - tampouco se promove uma discussão reflexiva sobre o caráter descritivo dos gêneros. Apresenta-se sua evolução histórica (por exemplo, a trajetória do trovadorismo à poesia moderna brasileira), mas não se reflete sobre a poesia (ou qualquer outro) como um gênero sempre em transformação, como propõem, por exemplo, Wellek e Warren ${ }^{28}$.

\footnotetext{
${ }^{27}$ Ver mais em: DINIZ, Ligia G. Entre o obrigatório e o proibido: a literatura e o leitor em livros didáticos de língua portuguesa para Ensino Médio. Dissertação de mestrado em Literatura, Universidade de Brasília, Brasília, 21 mai. 2012, p. 88 e seguintes. ${ }^{28}$ WELLEK, René; WARREN, Austin. Teoria da literatura. Lisboa: Europa-América, 1971, p. 285 e seguintes. 
Além disso, ao tomar dos formalistas ou dos estruturalistas determinadas concepções sobre gêneros, por exemplo, nas teorias da narrativa, o ensino de literatura pode produzir uma visão mais normativa dos elementos dos gêneros e inibir uma leitura (e mesmo uma escrita) criativa por parte dos estudantes. De modo geral, apresentam-se os gêneros como ferramentas para a interpretação dos textos, na medida em que funcionam como esquemas de recepção, que fazem parte das competências do leitor ${ }^{29}$, embora não se problematize, como se disse, a potencial transformação desses mesmos esquemas/competências, o que deixa o estudante despreparado para abordar um texto que não corresponda aos critérios que determinariam os gêneros apresentados. Em última análise, no entanto, é sempre à questão da representação - entendida como a relação entre obra e realidade - que voltamos quando deparamos com problemas na abordagem da literatura em sala de aula, na medida em que é apenas pela relação entre obra e leitor que podemos cativar este último. Assim, nada mais fundamental do que pensar formas mais ricas de encarar essa relação. É o que pretendemos fazer a partir da radicalização proposta por Gumbrecht, que abordamos a seguir.

\section{Gumbrecht e a presença}

Se Costa Lima, a partir da revisão da representação, pelo viés da mimesis aristotélica, propõe que o leitor é parte (criativa) da experiência mimética por meio do efeito possibilitado pela reverberação da cena da produção na expressão da recepção, ele concentra ainda sua proposta no foco em um sentido, circunscrito por um controle do imaginário, configurado a partir de um horizonte cultural de expectativas e provocador de um efeito. Com um ponto de partida bastante diferente, e sem problematizar a fundo a relação do sentido com uma ideia de verdade estável, Ricoeur reflete, a partir da relação do ser humano com o tempo, mediada pela narrativa, sobre o sentido proposto pela referência metafórica e não descritiva. Este artigo tem como objeto de reflexão a relação histórica entre os estudos literários (e o ensino de literatura) e a busca de sentido, ou a interpretação de obras a partir dessa busca. Com isso em mente, propõe-se agora uma reflexão a partir dos últimos trabalhos de Hans Ulrich Gumbrecht, que se concentram sobre não mais (apenas) a experiência literária como a busca por um sentido, mas também como a busca pelo que vai chamar de presença.

\footnotetext{
${ }^{29}$ Ver: COMPAGNON, Antoine. O demônio da teoria: literatura e senso comum. Belo Horizonte: Editora UFMG, 2012, p. 157. 150 | E N S A I O S
} 
O primeiro desses trabalhos, Produção de presença, estabelece uma defesa da recuperação de outra possibilidade de se relacionar com o mundo a partir de textos literários e outros objetos culturais - que não a busca pelo entendimento de seu sentido. Para Gumbrecht, vivemos, pelo menos desde o século XIX, nas artes e humanidades, uma incontestada centralidade da interpretação. O que ele propõe, em contraposição a isso, é "uma relação com as coisas do mundo que possa oscilar entre efeitos de presença e efeitos de sentido", sob a justificativa de uma espécie de reapropriação do mundo pelo corpo e os sentidos, sem que o impacto dessa relação seja atenuado, ou ao menos para que se limite o enfraquecimento do impacto das coisas sobre nós provocada pela atribuição de sentido a elas e à relação que estabelecemos com elas ${ }^{30}$. Nesse contexto, a experiência estética é definida por ele como uma oscilação, uma interferência ou uma tensão entre os "efeitos de presença" e os "efeitos de sentido".

Já em Atmosphere, Mood, Stimmung, o autor se concentra especificamente na literatura e propõe a releitura de um conceito filosófico, Stimmung - tradicionalmente associado à harmonia -, como produtor de uma terceira via para os estudos literários, para além da desconstrução e dos estudos culturais, que, para Gumbrecht, dominam a cena acadêmica atual. O autor recusa a ideia de representação como único paradigma em torno do qual se pode abordar a literatura, o que hoje apresentam aquelas duas correntes: enquanto para os estudos culturais o texto literário deveria representar a realidade extralinguística, para a desconstrução o texto "deveria querer fazê-lo, mesmo sabendo ser impossível" ${ }^{\text {"3 }}$.

Essa polarização em duas correntes que têm como paradigma a representação tem origem, segundo Gumbrecht ${ }^{33}$, mais de um século atrás, e redunda em uma tensão que o autor define como uma "crise da representação" e que localiza a partir do surgimento do "observador de segunda ordem": o homem não observa mais apenas o mundo, mas a si mesmo observando-o, o que leva à consciência da uma quantidade de perspectivas potencialmente sem limites e de uma variedade igualmente infinita de interpretações e possibilidades de se relacionar com o mundo e com cada objeto dentro dele. O passo seguinte é a perda de certeza sobre a possibilidade de um referente, ou seja, de um índice material no mundo. Ao

\footnotetext{
${ }^{30}$ GUMBRECHT, Hans Ulrich. Produção de presença: o que o sentido não consegue transmitir. Rio de Janeiro: Contraponto, Editora PUC-Rio, 2010, p. 14-15.

${ }^{31}$ Ibidem, p. 127

32 GUMBRECHT, Hans Ulrich. Atmosphere, Mood, Stimmung: on a Hidden Potential of Literature. Stanford: Stanford University Press, 2012, p. 2-5. Todas as traduções de passagens de Gumbrecht (2012) são nossas.

${ }^{33}$ GUMBRECHT, Hans Ulrich. Produção de presença. Op. cit., p. 23.
} 
mesmo tempo, se recupera a ideia do corpo como parte da observação do mundo, o que gera um duplo viés e a tentativa, ou busca frustrada, de compatibilizar a apropriação do mundo pelos conceitos e aquela pelos sentidos.

Essa crise, é evidente, tem origem muito antes. Como Costa Lima, também Gumbrecht procura fazer um percurso histórico da representação, agora a observando não pelo viés da mimesis, mas como uma forma de se relacionar com o mundo, ou como ele chama, a partir das "formas mutantes de autorreferência humana" ${ }^{34}$. Retomando a passagem da Idade Média à Moderna, o autor vê como central a passagem de um realismo simbólico, com o sentido inerente às coisas dado por Deus, à percepção do homem como excêntrico ao mundo e como uma entidade intelectual e incorpórea - é o surgimento do paradigma sujeito/objeto, que dará origem a uma forma de se relacionar com o mundo calcada na interpretação, como produção ativa de conhecimento sobre as coisas, a partir da noção de que as superfícies materiais exprimem sentidos mais profundos. Note-se, como já se viu antes, que a ideia de que há um sentido inerente às coisas do mundo permanece o que se modifica é a forma de conhecer esse sentido.

O Iluminismo, enquanto ápice do paradigma do conhecimento via interpretação, prevê de alguma forma a crise que se instalaria no século seguinte. Com o século XIX, com a já mencionada "crise da representação", de um mundo em que a cada fenômeno correspondia um conceito, passa-se a um mundo em que os fenômenos se identificam em narrativas, e em que se tenta conciliar a experiência conceitual com a percepção dos sentidos. Gumbrecht, observando o momento pelo ponto de vista alemão, afirma que a academia coloca uma pá de cal no assunto, ao menos oficialmente, decretando a impossibilidade de apreender o mundo a partir dos sentidos. Em termos formais, em Berlim, Dilthey propõe a secessão na universidade entre aqueles que buscavam conciliar corpo e intelecto, e aqueles que, como ele, tinham "a interpretação como prática nuclear e a hermenêutica como espaço de reflexão"35. Dessa forma, Gumbrecht conclui, a crise da representação leva, paradoxalmente, à entronização da hermenêutica nas humanidades: o mundo, ao menos no que diz respeito às disciplinas das humanidades, deve ser abordado pela razão e pela experiência interpretada.

\footnotetext{
${ }^{34}$ Sobre essa trajetória histórica, ver: GUMBRECHT, Hans Ulrich. Produção de presença. Op. cit., p. 62-63; GUMBRECHT, Hans Ulrich. Atmosphere, Mood, Stimmung. Op. cit., p. 65 e seguintes.

${ }^{35}$ GUMBRECHT, Hans Ulrich. Produção de presença. Op. cit., p. 67. 
A partir daí, o século XX vê a centralidade do sentido e da linguagem como construção do mundo, e, mais tarde, os mundos cotidianos e mentalidades como construções sociais da realidade, com a ascensão da sociologia e da história cultural e a consequente perda das outras referências de mundo. Ao longo do século XX, os estudos literários se alternarão, para Gumbrecht, entre abordagens "duras" e "suaves" para o problema/paradigma da representação, seja para reafirmá-la, seja para alegar sua impossibilidade, como se dá hoje na oposição que ele levanta entre estudos culturais e desconstrução. Para o autor, como se vê, a ideia de representação está intrinsecamente relacionada à ideia de sentido, em oposição à de presença. Apesar de, diferentemente, entender que a representação está sempre em jogo quando se fala de qualquer relação que o leitor possa estabelecer com o mundo via obra literária, julgamos de fundamental importância a relação que Gumbrecht propõe quando fala em leitura por Stimmung. Nela, o foco estaria na "dimensão textual das formas que nos envolvem e a nossos corpos como uma realidade física - algo que pode catalisar sentimentos [ou sensações] internos sem a questão da representação estar necessariamente envolvida" ${ }^{36}$. Todos os elementos do texto podem contribuir para a produção de atmosferas. Essa proposta interessa particularmente quando se pensa numa relação entre literatura e leitores ainda não habituais ou preparados, na medida em que a leitura por Stimmung segue um processo mais instintivo. É o próprio Gumbrecht quem afirma: "Esta é a orientação de uma boa parte dos leitores não profissionais", apesar de eles não saberem, nem precisarem saber, disso ${ }^{37}$.

O conceito de Stimmung, ou sua reelaboração, é resultado de um esforço que já estava presente pelo menos desde Produção de presença, ao mesmo tempo que a dificuldade em delimitar seu alcance ou defini-lo com exatidão está no cerne da própria dificuldade em se criarem conceitos que estejam relacionados a uma prática ou relação não interpretativa, até mesmo pela acusação de ingenuidade que recai sobre quem, nas humanidades, busca apreender o mundo que não pelo entendimento ${ }^{38}$. O que está em jogo, no entanto, não é apenas a desconsideração de um modo de apreensão não interpretativo, mas também, com mais prejuízo, o desprezo (acadêmico) por tudo o que não pudesse ser apreendido a partir de seu sentido ou apenas de seu sentido, o que inclui a experiência estética, tomada como uma vivência

\footnotetext{
${ }^{36}$ GUMBRECHT, Hans Ulrich. Atmosphere, Mood, Stimmung. Op. cit., p. 5.

${ }^{37}$ Ibidem, p. 13.

${ }^{38}$ GUMBRECHT, Hans Ulrich. Produção de presença. Op. cit., p. 77 
de efeitos de sentido e de presença. Fica claro, portanto, que o que se propõe não é uma revolução total, inviável, em que as humanidades deixariam de se ocupar de fenômenos de significação, apenas que se considerem outros tipos de fenômenos 39 .

A coexistência dos dois tipos de fenômenos (e a tensão entre seus efeitos) e dos dois tipos de apropriação do mundo não deve ser, para Gumbrecht, confundida com a ideia de que a obra de arte deve carregar, via experiência estética, uma mensagem ética, o que traria como corolário a noção de que um estudo sócio-histórico dos artefatos culturais permitira melhor compreender seu valor estético ${ }^{40}$. Essa reserva não exclui, no entanto, a dimensão histórica da experiência estética, mas na leitura por Stimmung, diferentemente, as duas experiências - histórica e estética - se confundem nas atmosferas e estados de espírito produzidos pela obra e comunicados ao leitor. Quando se pensa no engessamento que a abordagem historiográfica inflige ao ensino escolar de literatura, pode-se compreender como uma leitura menos dependente de contextualizações históricas prévias (e, em grande parte, toscas) pode trazer consigo uma vitalidade perdida. $O$ autor defende justamente que a obra, em si própria, faça o trabalho de inserir o leitor em realidades passadas, de modo a fazê-lo "encontrar alteridades [otherness] de maneiras íntimas e intensas"41. Essa proposta lembra a de um último Todorov, que, preocupado justamente com as abordagens institucionais da literatura, especialmente a escolar, afirma que - embora ainda entenda o sentido como fim indiscutível da obra - não só a literatura abre potencialmente ao infinito nossas possibilidades de interação como tem a vocação de nos fazer sentir adotando o ponto de vista dos outros, experiência cujo horizonte "não é a verdade, mas o amor, forma suprema de ligação humana" ${ }^{42}$.

Esse efeito de proximidade - ou, extrapolando, essa dimensão do amor de que fala Todorov - é quase sempre evitado ou desprezado na leitura que busca o sentido mais do que uma experiência subjetiva de presentespassados ("past presents"). Para Gumbrecht, a aproximação entre leitores e outras realidades é produzida em diferentes dimensões e partir de diferentes elementos textuais e acontece "sem que seja necessário entender o que essas atmosferas e estados de espírito significam; não precisamos saber que

\footnotetext{
${ }^{39}$ GUMBRECHT, Hans Ulrich. Uma questão de sentido. O Globo, p. 5. Rio de Janeiro, 2011.

${ }^{40}$ GUMBRECHT, Hans Ulrich. Produção de presença. Op. cit., p. 122.

${ }^{41}$ GUMBRECHT, Hans Ulrich. Atmosphere, Mood, Stimmung. Op. cit., p. 12-13.

${ }^{42}$ TODOROV, T. A literatura em perigo. Rio de Janeiro: Difel, 2010, p. 81. 
motivações ou circunstâncias os ocasionaram" "43. Retomando o foco deste artigo, essa proposição, no entanto, soaria como uma blasfêmia - ou no mínimo pareceria muito desorientadora ${ }^{44}$ - àqueles que se ocupam, em quaisquer níveis, da organização curricular de literatura no ensino médio; afinal, concentrar a abordagem de uma obra em seu valor estético-ético (a estética transportando a ética e sendo preenchida por ela) dá uma base de orientação pedagógica bem mais precisa ${ }^{45}$.

De fato, essa ainda é a premissa básica, uma espécie de ponto de partida teórico mas também pragmático segundo o qual se estabelece a abordagem da literatura ou as propostas de leitura literária observadas na escola. Com isso, aliena-se a possibilidade de um contato mais íntimo com os textos que os estudantes talvez pudessem travar, fosse a imposição de sentido mais frouxa (ou generosa). Encarar o ensino escolar de literatura como um misto de história da literatura com uma (re)afirmação dos valores éticohumanistas da leitura literária - da literatura como esse transporte estético de carga ética - não é, em si, completamente condenável. O que faz pouco ou nenhum sentido é esperar que esse processo redunde na formação de leitores, entendida, é claro, não (apenas) como a preparação ou capacitação de sujeitos para o entendimento e interpretação de textos literários, mas como um encantamento dos estudantes pela leitura literária - posto, naturalmente, que a leitura literária não se opera apenas no nível intelectual, mas absorve todo o corpo, desde o fascínio tátil (mas também visual e olfativo) pelo objeto livro, passando pela a produção de imagens menos ou mais mediadas pelo entendimento, até a emoção em alguma construção mais comovente. Ou seja, a literatura nos desloca da posição imóvel necessária à interpretação de um sentido menos imediato, a um espaço configurado, ou preenchido, pelo que Gumbrecht vai chamar de Stimmung.

Quando o foco é o ensino de literatura, ou a leitura literária como, explicitamente ou não, defendida pela academia (como se sabe, o que mais se produz nas universidades são textos de crítica literária em que se busca alguma relação mais ou menos objetiva entre as obras e o mundo), o esforço em se desviar dos "efeitos de presença" é notável, mesmo nos casos em que isso se dá com mais dificuldade ou estranheza. A poesia é o caso mais exemplar, e obviamente isso não passa despercebido a Gumbrecht: "Nem o

\footnotetext{
${ }_{44}^{43}$ GUMBRECHT, Hans Ulrich. Atmosphere, Mood, Stimmung. Op. cit., p. 14, grifos meus.

${ }^{44}$ Em resposta a uma resenha do livro Produção de presença, escrita pela professora Andrea Daher, do Departamento de História da UFRJ, Gumbrecht lembra uma reserva acadêmica tradicional "relativa à legitimação da experiência estética" por esta ser "demasiado subjetiva". GUMBRECHT, Hans Ulrich. "Uma segunda resposta "cordial"”. O Globo, p. 5. Rio de Janeiro, 2011.

${ }^{45}$ GUMBRECHT, Hans Ulrich. Produção de presença. Op. cit., p. 122. 
domínio institucional mais opressivo da dimensão hermenêutica poderia reprimir totalmente os efeitos de presença da rima, da aliteração, do verso e da estrofe" ${ }^{46}$. Ora, arrisco dizer que a escola, especialmente no ensino médio, realiza de forma bastante eficiente essa repressão, por meio de exercícios exaustivos de interpretação de texto (com respostas prontas e fechadas, em boa parte), de tarefas de explicação e localização de figuras de linguagem, alinhadas ainda a uma - caindo em desuso, é verdade - cobrança sobre conhecimentos de forma: tipos de rima, métrica, etc.. É claro que o sistema escolar não tem como bloquear todo e qualquer efeito de presença de um poema - a subjetividade da experiência encontra seus modos de se desviar desses bloqueios -, mas a rejeição quase generalizada à poesia pelos adolescentes (com a exceção, pode-se dizer, de certa poesia ultrarromântica) é uma boa pista do sucesso da opressão institucional escolar. Escapa dessa opressão apenas aquele aluno que, por uma inclinação pessoal forte, ou por uma vivência extraescolar importante, se relaciona com o poema de maneira suficientemente pessoal a ponto de neutralizar a imposição de sentidos ou conhecimentos estruturais.

A centralidade do tempo na forma de relação do homem com o mundo também é importante para a proposta de reflexão teórica de Gumbrecht e pode ser mais uma pista de como a imposição de interpretações afeta a leitura literária na escola. A oposição tempo/espaço é destacada, é claro, pelo autor alemão, que vai afirmar que "o tempo é a dimensão primordial em qualquer cultura de sentido, pois parece existir uma associação inevitável entre a consciência e a temporalidade" ${ }^{47}$, enquanto o espaço é a dimensão da presença. Mais tarde, ao questionar como chegar ao "intenso apaziguamento da presença", Gumbrecht propõe a ideia de "redenção", como estado "a atingir por meio do paradoxo do êxtase, isto é, forçando uma relação inicial, uma dada situação de distância, até um grau de excentricidade, na esperança de uma união - melhor ainda, de uma presença-no-mundo". Esse estado, diz, seria a redenção de uma obrigação de movimento e mudança imposta pelo cotidiano, ou seja, estaria ligada à redenção da própria centralidade do tempo, em sua relação com o sentido ${ }^{48}$.

Lembra-se aqui, é claro, o ponto de partida que Ricoeur toma quando defende que a mimesis aristotélica pode ser completada por um último estágio, em que o receptor, em fusão com o mundo do autor/texto, irá

\footnotetext{
${ }^{46}$ Ibidem, p. 40.

${ }^{47}$ Ibidem, p. 110

${ }^{48}$ Ibidem, p. 169-170 
completar a representação. Ricoeur afirma que a experiência humana está em busca de narrativa - ainda mais, propõe que haja uma "estrutura pré-narrativa da experiência" " tornam mais "legíveis" ("lisibles") quando são interpretadas em função das histórias que as pessoas contam sobre si mesmas e que essas "histórias de vida" se tornam mais inteligíveis quando a elas se aplicam modelos narrativos - roteiros - emprestados tanto da história quanto da ficção ${ }^{50}$. Não à toa, Ricoeur fundamenta sua filosofia da narrativa em Agostinho, que, ele mesmo, já nos sugeria algo como uma ficcionalização do passado, ao afirmar que "a memória relata não os próprios acontecimentos que já decorreram, mas sim as palavras concebidas pelas imagens daqueles fatos, os quais, ao passarem pelos sentidos, gravaram no espírito uma espécie de vestígios" ${ }^{\text {"5l }}$. Retomo essa questão aqui para, mesmo como exemplo, contrapor a proposta de interação do receptor com o texto via tempo em Ricoeur (a narrativa como produtora de sentido) à proposta de Gumbrecht de interação do leitor com a obra via espaço (presença).

Assim, posições, que entendo políticas, tanto de Ricoeur, com a "mimese III", quanto de Costa Lima, com a "representação-efeito", que buscam, enquanto revisões epistemológicas, reapropriações da mimesis aristotélica - mesmo sem uma agenda explícita -, colocam em posição central a recepção como produção de sentido pela interseção dos mundos do autor e do receptor. Gumbrecht, por sua vez, vai mais além, ou caminha em outra direção, ao questionar o sentido como única forma de interseção entre esses mundos, ou entre o leitor e o mundo via obra de arte. É por isso que suas propostas teóricas ocupam lugar de destaque neste artigo: uma abordagem da leitura literária centrada apenas no sentido ignora uma parte importante da experiência estética, que é fundamental para que alguém se torne um leitor. Isso não quer dizer, de forma alguma, que o sentido deva ser abolido do ensino de literatura, sob pena de se ignorarem as funções mais centrais da instituição escolar, quais sejam as de preparar a criança e o jovem para a vida em uma sociedade que é centrada no, ou construída sobre o, sentido. No entanto, e aí se extrapola o âmbito do ensino de literatura, limitar o ensino médio à interpretação de textos na concepção mais renascentista do termo - a certeza de que existe uma verdade alcançável ali, ainda que esta vagueie, segundo a conveniência, da identificação de valores

\footnotetext{
${ }^{49}$ RICOEUR, Paul. Tempo e narrativa. Op. cit., p. 114.

${ }^{50}$ RICOEUR, Paul. Narrative identity. Philosophy today, n. 35, p. 73-81, 1991, p. 73

${ }^{51}$ AGOSTINHO. Confissões. Op. cit., p. 11, 18. 
universais até a explicação a partir de intenções do autor enquanto gênio não pode produzir, em larga escala, estudantes preparados ou dispostos à reflexão que (determinados) cursos universitários deles exigem.

É por esses dois motivos - a preparação para o pensamento reflexivo e a experiência estética que possibilita a formação de leitores - que o questionamento sobre a dominação da interpretação no ensino escolar de literatura nos parece relevante. Essa preocupação é central no relato de Gumbrecht sobre um curso de Introdução às Humanidades que ele, ao lado de um professor de Música, deu a alunos do primeiro ano na Universidade de Stanford e no qual a proposta era oferecer diferentes tipos de experiência estética: "Só queríamos apontar para diferentes modalidades de fruição das coisas belas, sem tornar a experiência estética uma obrigação" (e como se o faria?); "não tentamos argumentar a favor da experiência estética fazendo uma alusão a quaisquer valores que estivessem além do sentimento intrínseco de intensidade que ela pode causar" ${ }^{52}$. O foco não se resumia a obras ou objetos normalmente associados à experiência estética (como uma ária de Mozart ou um poema de Federico García Lorca), mas incluía momentos esportivos, touradas, visitas a edifícios. Além disso, é claro, não se buscavam experiências que redundassem em mensagens éticas: a ideia era concentrar-se no momento, ou melhor, na intensidade do momento, como um deslocamento (e um descolamento) do mundo cotidiano.

Aqui se retoma uma dupla implicação de uma leitura para a presença ou por Stimmung em um ambiente de ensino. Em primeiro lugar, esse tipo de leitura, cujo objetivo é produzir uma experiência estética - sempre momentânea, e jamais previsível, ainda que provocada -, deve partir do isolamento do mundo cotidiano, o que sempre gera dificuldades práticas, quando se pensa numa sala de aula, por exemplo, de ensino médio. Ao mesmo tempo, essa leitura deve provocar um isolamento do mundo cotidiano, o que supõe entender que tipos de objetos, culturalmente específicos, por um equilíbrio de palpabilidade e encanto, são capazes de despertar a possibilidade de uma experiência estética nos moldes propostos por Gumbrecht, ou seja, como aquela oscilação entre efeitos de sentido (do lado da palpabilidade) e efeitos de presença (como produtores de encantamento, atmosferas, climas). Nesse sentido, é fundamental que não se limite a análise dessa experiência ao receptor e suas operações, mas também que se debruce sobre os objetos que possibilitam a experiência estética, sempre com a consciência de que não existe um modo sistemático ou

${ }^{52}$ GUMBRECHT, Hans Ulrich. Produção de presença. Op. cit., 2010, p. 125

158| E N S A I O S 
pedagógico de levar os estudantes a vivenciar esse tipo de experiência, assim como não há certeza sobre o que ela traz às nossas vidas ${ }^{53}$.

\section{Comentários e possibilidades}

Traçando uma ponte, às vezes naturalmente frágil, entre os pensamentos de três autores contemporâneos, pensamos ter oferecido algumas chances de repensar a imposição de interpretações - ou da necessidade de interpretação, no caso de Gumbrecht - na abordagem da leitura literária na escola, em especial no ensino médio, onde essas imposições se fazem mais presentes, se não por uma simples questão de acomodação ao hábito, pela subordinação do ensino de literatura (como das outras disciplinas) aos exames de admissão no ensino superior. Se pensarmos nos exercícios de compreensão textual padrão nesses exames, em que se pede a alternativa correta entre múltiplas escolhas ou a atribuição de um simples "certo" ou "errado" - ou "verdadeiro" e "falso", para lidar com conceitos ainda mais categóricos -, fica a sensação de que há muito pouca margem de manobra para repensar o modus operandi atual. Cremos, no entanto, que, a partir do momento em que nós, estudiosos da literatura, nos definimos, ao menos a princípio, pelo encantamento que ela nos provoca, precisamos buscar dentro das nossas próprias reservas teóricas e reflexivas, algumas forma de garantir minimamente o acesso dos estudantes especialmente daqueles que, por contextos socioculturais, não estão inseridos nesse ambiente - à possibilidade de uma experiência literária mais completa, que não se situe apenas no plano do entendimento, ainda mais o de uma verdade prévia proposta.

Representar o mundo, interpretar o mundo, estar no mundo não existem em domínios isolados. Entendemos, como dito, que a escola tem por papel, talvez central, inserir o estudante em uma sociedade interpretativa - e isso vale para todas as disciplinas -, mas é preciso repensar essa ideia, e essa prática, de interpretação. Nesse sentido, a tomada de partido tanto de Costa Lima quanto de Ricoeur, ainda que situados em planos bastante distintos, no sentido de se reapropriar da mimesis aristotélica e entender a representação (também) como a fusão de horizontes entre autor/obra e leitor, ou como uma via dupla entre eles, é importante para essa reavaliação. Não é um problema em si interpretar, se relacionar pelo sentido, ou mesmo propor uma

${ }^{53}$ Ibidem, p. 129 e seguintes.

$159 \mid$ E N S A I O S 
interpretação, mas é problemático não se refletir sobre como uma interpretação dependerá sempre do ângulo a partir do qual se produziu.

As Orientações curriculares do MEC de alguma forma já propõem algo diferente de uma ideia de interpretações corretas, e a participação do leitor como construtor de significações, ao afirmar que é necessário um "contato efetivo com o texto", que produz uma "sensação de estranhamento", a partir da qual o "leitor contribui com sua própria visão de mundo para a fruição estética" ". Entretanto, falha, por um lado por não propor, substancialmente, alternativas à organização historiográfica, e por outro por simplesmente não penetrar na instituição escolar, seja via livros didáticos seja na prática de sala de aula, o que também é responsabilidade das licenciaturas de Letras, que em boa parte pouco se preocupam em fazer os futuros professores refletirem sobre o que é literatura ou leitura literária ${ }^{55}$. É nesse sentido que recuperar um conceito tradicional para repensá-lo pode ser produtivo na reflexão sobre a própria relação que estabelecemos, nós, os professores, com a literatura. Entender como, historicamente, se exigiu da ficção ou da poesia um tributo à verdade, como propõe Costa Lima, ou refletir sobre a solução poética que a narrativa oferece à nossa relação conflituosa com o tempo, e que, nesse sentido, essa solução só se completa com o reconhecimento do leitor, via um horizonte cultural comum com o texto, pode ser uma forma de repensarmos a leitura literária que queremos ajudar nossos estudantes a desenvolver.

Entretanto, a principal dificuldade que se impõe quando o objetivo propalado é o de formar leitores é uma reflexão pobre sobre como trazer o estudante para as possibilidades da experiência estética. Isso porque se insiste na exclusividade do conhecimento intelectual, quando ele, sozinho, não dá conta da vivência literária. As próprias Orientações curriculares acabam por confundir ética e estética de uma forma que fica difícil supor uma experiência em que a vivência estética, como definiu Gumbrecht, não seja carregada de uma obrigação, para ter valor, de transportar uma mensagem ética: "Quanto mais profundamente o receptor se apropriar do texto e a ele se entregar, mais rica será a experiência estética, isto é, quanto mais letrado literariamente o leitor, mais crítico, autônomo e humanizado será" ${ }^{56}$. Indo além, o texto dá a crer que o leitor que não estabeleça uma relação primeiramente de sentido com o texto ocupa um lugar de sujeição: "Formar para o gosto literário [...] e

\footnotetext{
${ }^{54}$ BRASIL. Orientações curriculares para o ensino médio. Op. cit., p. 55.

${ }^{55}$ Tome-se como exemplo a Universidade de Brasília, cuja licenciatura em Letras exige que se curse apenas uma disciplina teórica (Introdução à Teoria da Literatura), no primeiro período, para depois passar às escolas literárias (Barroco, Romantismo, etc.).

${ }^{56}$ Ibidem, p. 59-60.

$160 \mid$ E N S A I O S
} 
oferecer instrumentos para uma penetração mais aguda nas obras decerto supõem percorrer o arco que vai do leitor vítima ao leitor crítico" ${ }^{\text {"57. }}$.

Não se propõe aqui uma "leitura selvagem" de textos na escola. Insistimos na importância de conduzir os estudantes a uma leitura interpretativa e crítica - mas não sempre. Não se o objetivo for formar leitores - processo entendido aqui como criar o hábito de leitura nesses jovens. Uma qualidade essencial à experiência estética é seu caráter fugidio: podemos criar as condições de sua presença, mas não garantir que ela ocorra e, sobretudo, que ela dure. Essa volatilidade é o que faz com que, depois de lermos um livro incrível, queiramos reviver uma experiência da mesma ordem e busquemos outro livro, e outro, e outro. Talvez seja necessário, enfim, que o leitor seja, de vez em quando, vítima do texto para que este exerça suas possibilidades sobre ele. Ler, afinal, para qualquer leitor, "não é simplesmente uma atribuição de sentido. É o movimento interminável, o movimento alegre e doloroso entre perder e voltar a ganhar controle intelectual e orientação" e só pode acontecer sem que se espere sempre uma solução ou resposta ${ }^{58}$.

Mais do que isso, ou ainda dentro dessas possibilidades, creio ser necessária uma recuperação das materialidades do texto. Práticas que hoje podem ser consideradas ingênuas - ler um conto ou um poema em voz alta para os estudantes - podem ser surpreendentemente produtivas. Da mesma forma, a criação de determinadas ambientações, de um isolamento mesmo forçado do mundo cotidiano, e o oferecimento de textos ou outros objetos culturais para que se possa viabilizar uma experiência estética, que não necessariamente ocorrerá, é claro. O professor, nesse sentido, funcionaria como um "catalisador de eventos intelectuais", que seriam proporcionados pelo entusiasmo provocado na interação entre ele e os alunos, como Gumbrecht propõe a respeito do ensino universitário de humanidades. Não queremos ser ingênuos no sentido de propor que uma tentativa que já pode resultar precária no ensino superior - penso aqui, por exemplo, na proposta de "convidar os alunos à serenidade" - seja realizada com sucesso pleno no ensino médio, mas é a partir de projetos mais ou menos utópicos que chegamos a algum tipo de mudança.

Uma possibilidade mais evidente e mais avessa a críticas desanimadoras, ainda que pouco trabalhada, é a da escolha de textos que

\footnotetext{
${ }^{57}$ Ibidem, p. 69.

${ }^{58}$ GUMBRECHT, Hans Ulrich. Produção de presença. Op. cit., p. 159.

${ }^{59}$ Ibidem, p. 132. 
envolvam, ou possam envolver o estudante, em uma atmosfera/estado de ânimo (Stimmung) que o transporte para outra realidade. A maior parte dos estudos sobre ensino de literatura concentra-se sobre modos de recepção e menos sobre os objetos estéticos, o que resulta, talvez, em um pouco investimento em textos envolventes, ou que, ainda, possibilitem leituras envolventes, que podemos oferecer aos estudantes. Quantas vezes, em sala de aula ou não, obtivemos uma experiência de leitura completamente diferente daquela que havíamos feito sozinhos, ao discutirmos com outra pessoa a leitura de um livro - algumas em que passamos a admirar um texto que, antes, havíamos desconsiderado? E quantas dessas vezes essa mudança se operou não porque o outro leitor desse uma interpretação diferente daquelas que havíamos produzido, mas porque, por algum ponto do texto que o tivesse tocado, nosso interlocutor nos contagiasse com alguma emoção que o texto em si, por circunstâncias a ele inerentes ou não (a leitura em um local barulhento, por exemplo), não houvesse provocado? E mais: quantas vezes uma obra de arte perde a graça quando outro leitor, um amigo ou um professor, oferece uma interpretação à qual não havíamos atinado e que, por algum motivo, estraga a experiência - mais de presença que de sentido - que havíamos vivido diante da obra? Ou ainda: quantas são as obras que chegam até nós com tantas camadas de sentidos já construídos que perdemos, ao menos alguns de nós, menos protegidos contra isso, a possibilidade de uma relação de presença (ou de uma leitura por Stimmung), com ela? Enfim, quantas vezes uma experiência de sentido empobrece não só a experiência de presença - como deve ser, segundo a proposta de oscilação entre as duas que propõe Gumbrecht - mas a experiência estética como um todo?

É claro que privilegiar a experiência estética como produção de presença, mesmo que de vez em quando, tem a ver com aceitar algo que tem pouco a ver com o caráter disciplinar, um dos fundadores da instituição escolar. Mas, se admitimos a possibilidade de que a leitura a partir de atmosferas e estados de espírito - sobre os quais não temos controle e que condicionam nossos sentimentos e comportamentos ${ }^{60}$ - pode levar a uma experiência de leitura mais completa, penso que vale pensar essa possibilidade. Colocar algo acima da ideia de controle, sobretudo quando estamos pensando em uma sala de aula repleta de adolescentes, parece sempre assustador, mas acredito que pode ser surpreendentemente produtivo. (E nunca saberemos sem tentar.).

${ }^{60}$ GUMBRECHT, Hans Ulrich. Atmosphere, Mood, Stimmung. Op. cit., p. 9 